\title{
Pengolahan Citra Obyek dari Balik Penghambur dengan Metoda Optik (Tapis Ruang) dan Metoda Digital ("Or Minimum")
}

\author{
E. Juliastuti ${ }^{1}$, A. Handojo ${ }^{1}$, Bambang S. P. Abednego ${ }^{1}$ \& Moedji Raharto ${ }^{2}$ \\ ${ }^{1}$ Departemen Teknik Fisika - FTI - Institut Teknologi Bandung \\ ${ }^{2}$ Departemen Astronomi - FMIPA - Institut Teknologi Bandung
}

\begin{abstract}
Abstrak. Dalam makalah ini dilaporkan peningkatan kualitas citra obyek dari balik penghambur dengan cara optik dan cara digital. Perangkat optik yang sederhana menggunakan lensa positif dan tapis ruang berbentuk lubang lingkaran kecil berhasil pada tahap pertama memberikan citra yang dapat diamati.

Kualitas citra dari perangkat optik diukur dengan dua besaran. Pertama ialah koefisien korelasi, yaitu derajat kesamaan skala keabuan piksel pada citra asli tanpa hamburan dengan citra yang mengalami hamburan. Kedua ialah Peak Signal-to-Noise Ratio (PSNR) yaitu peningkatan kualitas citra hasil pengolahan dibandingkan citra asli. Dari percobaan didapat bahwa harga PSNR makin kecil dengan makin besarnya diameter tapis ruang. Koefisien korelasi optimum $(0,368)$ didapatkan pada diameter tapis $1,6 \mathrm{~mm}$.

Selanjutnya pengolahan citra secara digital didasarkan asumsi bahwa penghambur selalu bergerak secara acak. Pada beberapa diameter tapis ruang, citra direkam dengan kamera CCD yang dihubungkan pada komputer. Perekaman dilakukan berulang-ulang dengan posisi penghambur berubah-ubah. Sejumlah citra terekam kemudian diolah dengan metoda "or minimum", dan metoda perata-rataan sebagai pembanding.

Pada metoda "or minimum", untuk membentuk citra baru diambil intensitas terkecil dari piksel pada posisi yang sama dari sejumlah citra. Pada metoda perata-rataan, intensitas setiap piksel pada posisi yang sama dari sejumlah citra dirata-ratakan guna menghasilkan citra baru.

Hasil pengolahan dengan metoda "or minimum" mempunyai peningkatan PSNR (terbesar 4,00 dB) yang lebih besar dibandingkan metoda perata-rataan (terbesar $1,04 \mathrm{~dB}$ ). Peningkatan koefisien korelasi terbesar 0,072 pada metoda "or minimum" dan 0,05 pada metoda perta-rataan.
\end{abstract}

Kata kunci: tapis ruang; “or minimum”; PSNR; koefisien korelasi.

Abstract. In this paper, optical and digital methods are combined to improve the quality of the image obtained through a scattering medium. The optical method, using simply an imaging positive lens and a small circular spatial filter, succeded in the first stage to form an observable image.

Two criteria were adopted to evaluate the quality of the image in the optical method. The first is Peak Signal-to-Noise Ratio (PSNR), the second is the correlation coefficient between the original image and the processed scattered

Makalah diterima redaksi tanggal 5 September 2005. 
image. It was found that PSNR decreased at a larger diameter of the spatial filter. The optimum correlation coefficient $(0.368)$ was found at a filter diameter of 1.6 mm.

Next, the digital image processing was conducted using the assumption that the scattering medium always moved randomly. Involving different diameters of the spatial filter, the image was recorded with a CCD camera connected to a computer. For each diameter, the image was recorded many times, each time with a different position of the scattering medium. The images were then processed with the so-called "or minimum" and the averaging method.

In the "or minimum" method, the gray level of the same pixel position of all images was compared to find its minimum value. The ensemble of pixels having the minimum gray level constitutes a new image. In the averaging method, the average gray level in each pixel position was computed from a number of images.

It appeared that the "or minimum" method yielded the best improvement in PSNR (the largest being $4.00 \mathrm{~dB}$ ) compared to the averaging method $(1.04 \mathrm{~dB})$. The improvement of the correlation coefficient was up to 0.072 in the "or minimum" method and 0.05 in the averaging method.

Keywords: spatial filter; “or minimum”; PSNR; correlation coefficient.

\section{$1 \quad$ Pendahuluan}

Pengamatan citra melalui media penghambur seperti kabut banyak menarik peneliti, karena kegunaannya antara lain untuk keselamatan lalu lintas, kedokteran $^{[1-2]}$ dan transmisi data optik.

Perangkat optik untuk pencitraan melalui penghambur umumnya memanfaatkan beda sifat antara sinar yang terhambur dan sinar yang tidak terhambur. Metoda yang menggunakan sifat koherensi adalah interferometri dan holografi ${ }^{[3-5]}$. Sementara itu time gating ${ }^{[6-8]}$, memanfaatkan sifat bahwa cahaya terhambur menempuh lintasan yang lebih panjang sehingga waktu tempuhnya lebih lama. Interferometri dan holografi memerlukan kestabilan perangkat optik yang sangat tinggi. Di pihak lain pemrosesan citra dengan time gating memerlukan saklar yang sangat cepat dalam orde femtosecond untuk dapat memisahkan sinar yang paling awal datang dari sinar-sinar berikutnya.

Pada penelitian ini digunakan metoda yang tidak memerlukan tuntutan tinggi seperti di atas, yaitu perangkat optik dengan hanya sebuah lensa positif dan tapis ruang berbentuk lingkaran, yang meskipun demikian terbukti mampu menghasilkan citra yang dapat diamati.

Citra optik yang direkam kemudian diolah secara digital dalam usaha mendapatkan kualitas yang lebih tinggi. Cara manipulasi multi/banyak citra 
yang banyak digunakan adalah metoda penjumlahan citra dan perata-rataan sejumlah citra $^{[9]}$. Pada kedua metoda ini, citra direkam berkali-kali pada saat yang berbeda. Pada penjumlahan citra, perekaman dilakukan dalam waktu yang singkat sehingga setiap rekaman citra mempunyai intensitas yang rendah. Penggunaannya untuk menghasilkan citra yang lebih tajam, misalnya pada perekaman obyek-obyek tata surya dengan kamera $\mathrm{CCD}^{[10]}$. Sementara itu metoda perata-rataan sejumlah citra umumnya digunakan untuk mengurangi noise dan mempertajam citra $^{[11]}$.

Untuk memperbaiki metoda perata-rataan, dipikirkan bahwa jika perata-rataan noise akibat hamburan menyebabkan naiknya intensitas maka untuk mengurangi noise dicari harga minimum setiap piksel dari sejumlah citra. Piksel-piksel dengan intensitas minimum kemudian digunakan untuk membentuk citra baru. Metoda ini dinamakan metoda "or minimum".

Pada percobaan diterapkan beberapa pembatasan masalah, yaitu terutama:

- Obyek di balik penghambur bersifat semi transparan dengan faktor transmisi 1 dan 0.

- Oleh karena penghambur alamiah seperti kabut sukar diperoleh dan dijaga karakteristiknya, digunakan penghambur pengganti yang memiliki karakteristik yang serupa yaitu kertas tissue.

\section{$2 \quad$ Pengolahan Citra dengan Tapis Ruang}

\subsection{Pembentukan Citra dengan Sebuah Lensa Positif}

Bila cahaya sejajar melalui obyek semi transparan kemudian mengenai lensa positif, maka sinar pembawa informasi citra akan dibiaskan melalui titik fokus lensa dan akan membentuk citra obyek pada bidang citra (lihat Gambar 1).

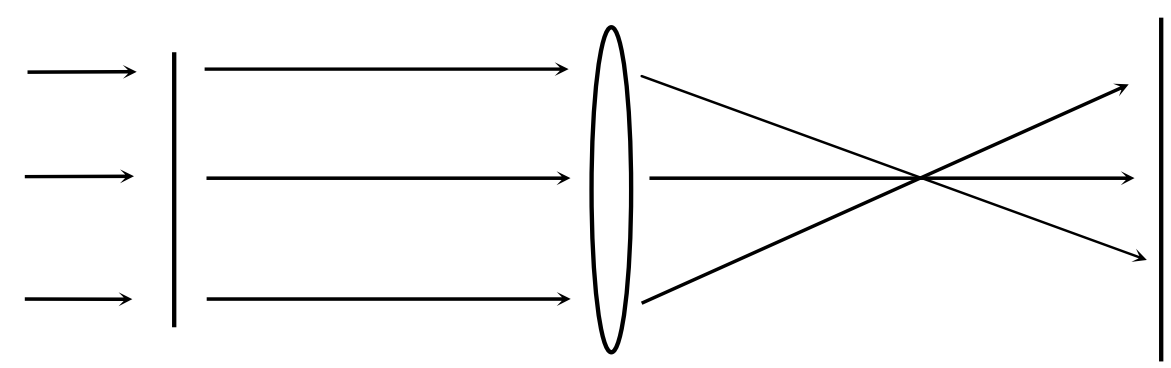

Gambar 1 Pencitraan dengan berkas sejajar. 


\subsection{Pencitraan dengan Adanya Media Penghambur}

Bila di antara obyek dan lensa terdapat media penghambur, maka cahaya pembawa informasi citra sebagian besar akan terhambur. Akibatnya sinar-sinar dengan arah yang menjadi acak itu setelah dibiaskan oleh lensa tidak akan membentuk citra (lihat Gambar 2a).

Telah banyak metoda ${ }^{[3-8]}$ yang diselidiki untuk memulihkan atau membentuk kembali citra melalui media penghambur. Pada penelitian ini digunakan metoda sederhana yang didasarkan pada adanya sebagian kecil cahaya dengan arah yang tetap sejajar karena lolos di sela-sela butir penghambur tanpa mengalami hamburan. Sinar-sinar tersebut sesudah dibiaskan lensa tetap melalui titik fokus, sedangkan sinar-sinar yang terhambur tidak melalui titik fokus. Dengan demikian jika digunakan tapis (filter) berupa penghalang dengan lubang kecil di tengahnya yang ditempatkan pada bidang fokus lensa, maka praktis hanya sinarsinar yang tidak terhambur akan lolos melalui lubang tersebut dan citrapun terbentuk, lihat Gambar 2b. Sebagian kecil sinar terhambur yang ikut lolos akan merupakan noise bagi citra.

Tapis yang melakukan seleksi cahaya berdasarkan lokasinya dalam ruang disebut tapis ruang. Diameter lubang yang berbentuk lingkaran akan berpengaruh terhadap kualitas citra $^{[12]}$, lihat nanti Bab 4. Secara teoretik, pengaruh diameter tapis dapat ditelusuri dengan meninjau susunan pada Gambar 2.b sebagai perangkat transformasi Fourier. Pada bidang fokus lensa (posisi tapis) terbentuk spektrum frekuensi ruang dari obyek. Penghalang dengan lubang di tengahnya dengan demikian berfungsi sebagai tapis lolos rendah dan akan mengurangi noise dari hamburan yang terutama mengandung frekuensi ruang tinggi. Aspek tersebut secara lebih rinci telah diuraikan sebelumnya ${ }^{[12]}$. Pada penelitian ini diperiksa efek pengolahan secara digital (dalam domain ruang/spasial) sebagai usaha selanjutnya dari peninjauan Fourier dalam domain frekuensi ruang.

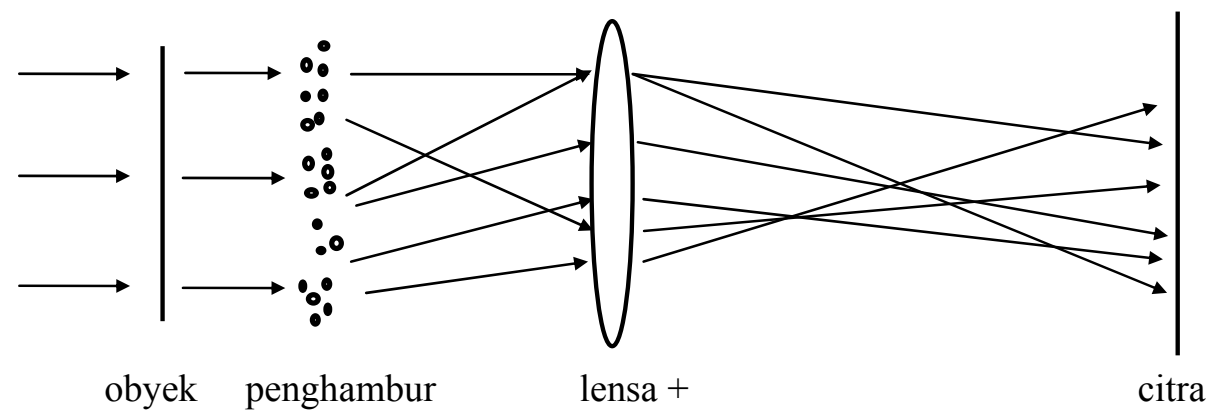




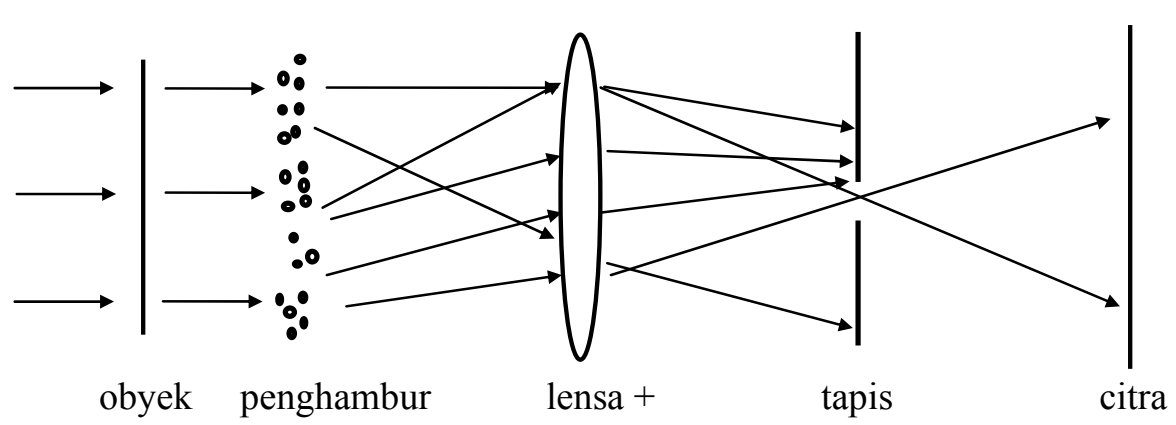

(2.b)

Gambar 2 a. Pencitraan dengan media penghambur.

b. Pencitraan dengan media penghambur dan tapis ruang.

\section{$3 \quad$ Pengolahan Citra Digital}

Citra dinyatakan oleh fungsi intensitas cahaya $i(x, y)$ dengan $x$ dan $y$ menyatakan koordinat ruang, $i(x, y)$ menyatakan derajat keabuan (gray level) pada citra monokrom hitam-putih. Pada citra digital, intensitas $i(x, y)$ telah didiskritkan dalam koordinat ruang dan derajat keabuannya. Meskipun obyek asli yang digunakan dalam penelitian ini bersifat biner (faktor transmisi 0 dan 1), namun akibat hamburan terbentuk citra yang mengandung derajat keabuan.

\subsection{Metoda Perata-rataan}

Metoda ini digunakan pada kumpulan citra yang saling berkorelasi. Contohnya adalah sejumlah citra yang didapat dari pemotretan berkali-kali sebuah obyek di balik penghambur dengan posisi penghambur yang berbeda. Pada metoda ini, derajat keabuan piksel dengan koordinat yang sama dari beberapa citra dirataratakan kemudian hasilnya digunakan untuk menyusun citra baru.

Citra yang mengandung noise akibat penghambur dituliskan sebagai $i(x, y)$ yang terbentuk karena penambahan noise $\eta(x, y)$ pada citra tanpa penghambur $f(x, y)$, dan dapat dinyatakan dalam

$$
i(x, y)=f(x, y)+\eta(x, y)
$$

Di sini digunakan dua asumsi. Pertama, noise selalu berubah secara acak terhadap waktu, sehingga setiap piksel $(x, y)$ pada citra yang satu memiliki noise yang saling tidak berkaitan dengan piksel $(x, y)$ pada citra yang lain. Kedua, nilai rata-rata noise pada piksel $(x, y)$ dari banyak citra akan menghasilkan intensitas yang lebih rendah dari pada intensitas citra. 
Asumsi pertama berlaku karena citra yang diolah berasal dari cahaya yang menembus media penghambur (kabut), dengan butir kabut yang selalu bergerak acak $^{[13]}$. Meskipun digunakan cahaya dari sumber laser yang koheren, gerakan acak butir penghambur menyebabkan hilangnya korelasi fasa antar sinar terhambur, sehingga keseluruhan berkas cahaya menjadi tidak koheren, terutama jika waktu perekaman lebih lama dari pada waktu gerak butiran kabut. Gejala ini sesungguhnya yang sudah dimanfaatkan pada pencitraan melalui penghambur dengan holografi dan interferens ${ }^{[3-5]}$. Asumsi kedua dipenuhi jika penapisan ruang berlangsung cukup efektif sehingga intensitas noise yang sampai pada bidang citra menjadi tidak dominan.

Hasil perata-rataan citra $\bar{i}(x, y)$ diperoleh dengan menuliskan:

$$
\bar{i}(x, y)=\frac{1}{M} \sum_{n=1}^{M} i_{n}(x, y)=f(x, y)+\bar{\eta}(x, y)
$$

dengan M adalah jumlah citra yang dirata-ratakan dan $\bar{\eta}(x, y)$ intensitas rata-rata noise. Walaupun diasumsikan $\bar{\eta}(x, y)<f(x, y)$, menurut Pers.(2) dan (1) terjadi penambahan intensitas oleh $\bar{\eta}(x, y)$ pada $f(x, y)$, dan ini berefek mengurangi kontras citra hasil perata-rataan. Meskipun demikian, karena noise di sini berbentuk bercak-bercak cahaya, noise yang telah dirata-ratakan $\bar{\eta}(x, y)$ menghasilkan citra yang lebih halus, relatif lebih bebas dari bercak-bercak. Ini memungkinkan pengenalan bentuk atau informasi secara lebih baik pada citra hasil pengolahan.

\subsection{Metoda "Or Minimum"}

Seperti yang disinggung di atas, terjadi kenaikan intensitas $i(x, y)$ terhadap $f(x, y)$ yang berefek menurunkan kontras (perbedaan antara intensitas maksimum dan intensitas minimum) pada citra. Sebagai penyempurnaan, digunakan metoda yang disebut "or minimum".

Metoda ini dapat dijelaskan dengan bantuan Pers.(1) dan seperti pada pembahasan sebelumnya noise $\eta(x, y)$ bersifat acak untuk setiap piksel dan aditif, sehingga noise pada suatu koordinat piksel tidak saling berkaitan dengan noise pada koordinat lainnya. Untuk mengurangi efek noise dicari harga minimum intensitas setiap piksel dari sejumlah citra. Harga minimum ini tidak lain merupakan harga intensitas yang paling dekat dengan $f(x, y)$ dan dapat dituliskan:

$$
\operatorname{Min}\{i(x, y)\}=\operatorname{Min}\{f(x, y)+\eta(x, y)\} \approx f(x, y)+\operatorname{Min}\{\eta(x, y)\}
$$


dengan Min \{\} menyatakan operasi pencarian harga minimum. Jadi dipilih derajat keabuan terkecil dari piksel-piksel berkoordinat sama pada lebih dari satu citra kemudian hasilnya digunakan untuk menyusun citra baru. Seperti pada metoda perata-rataan, pada citra akhir di sini juga terjadi penambahan intensitas, namun yang ditambahkan adalah $\operatorname{Min}\{\eta(x, y)\}$ yang lebih kecil dari pada $\bar{\eta}(x, y)$, sehingga kontras diharapkan tidak banyak berkurang.

"Or minimum" serupa dengan metoda "tapis minimum" ${ }^{\text {"[14] }}$ namun metoda yang terakhir ini beroperasi dalam domain waktu (temporal), sedangkan metoda "or minimum" dalam domain ruang (spasial). Metoda "tapis minimum" sangat baik digunakan untuk menghilangkan "salt noise", hal yang serupa diharapkan terjadi pada metoda "or minimum". Program pengolahan citra dengan metoda perata-rataan dan "or minimum" dibuat menggunakan perangkat lunak MATLAB ${ }^{[15]}$.

\subsection{Kriteria Peningkatan Kualitas Citra}

Untuk mengukur peningkatan kualitas citra setelah pengolahan, digunakan dua besaran yaitu korelasi sebagai derajat kesamaan citra dan Peak Signal-to-Noise Ratio yang menghitung dalam desibel peningkatan kualitas citra hasil pengolahan terhadap citra asli. Kedua besaran tersebut membandingkan pikselpiksel yang tepat sama posisinya dari dua citra yang berlainan.

\subsubsection{Korelasi $^{[16]}$}

Koefisien korelasi menyatakan derajat kesamaan antara dua sinyal. Apabila terdapat dua citra $f(x, y)$ dan $g(x, y)$, koefisien korelasi antara keduanya adalah

$$
r=\frac{\sum_{x} \sum_{y}\left(f_{x y}-\bar{f}\right)\left(g_{x y}-\bar{g}\right)}{\sqrt{\left(\sum_{x} \sum_{y}\left(f_{x y}-\bar{f}\right)^{2}\right)\left(\sum_{x} \sum_{y}\left(g_{x y}-\bar{g}\right)^{2}\right)}}
$$

dengan $\bar{f}$ dan $\bar{g}$ masing-masing nilai rata-rata derajat keabuan piksel citra $f(x, y)$ dan $g(x, y)$.

Pada penelitian ini dilakukan korelasi skala keabuan dari setiap piksel citra tanpa media penghambur dengan piksel citra yang mengalami hamburan. 


\subsubsection{Peak Signal-to-Noise Ratio ${ }^{[17]}$}

Citra tanpa penghambur ditinjau sebagai $f(x, y)$ yang terdiri dari $\mathrm{N} \times \mathrm{N}$ piksel dan citra hasil pengolahan adalah $g(x, y)$. Pertama dihitung harga rata-rata kuadrat kesalahan (mean squared error - MSE) dari citra hasil pengolahan dengan persamaan berikut:

$$
M S E=\frac{\sum[f(x, y)-g(x, y)]^{2}}{N^{2}}
$$

Akar rata-rata kuadrat kesalahan (root mean squared error - RMSE) adalah akar kuadrat dari MSE. Besaran PSNR dalam satuan desibel (dB) dihitung dengan menggunakan persamaan:

$$
P S N R=20 \log _{10}\left[\frac{255}{(M S E)^{1 / 2}}\right]=20 \log _{10}\left(\frac{255}{R M S E}\right)
$$

Harga sebenarnya tidak terlalu berarti, yang penting ialah perbandingan harga antara dua citra hasil pengolahan sebagai salah satu ukuran peningkatan kualitas citra.

\section{$4 \quad$ Percobaan}

\subsection{Perangkat Perekaman}

Perangkat untuk merekam citra ditunjukkan pada Gambar 3, sedangkan obyek semi transparan yang digunakan berukuran $2,3 \mathrm{~cm} \times 3,4 \mathrm{~cm}$ dan diperlihatkan pada Gambar 4.

Pada jarak $72 \mathrm{~cm}$ dari obyek dipasang penghambur P berupa kertas tissue (merk Passeo dalam kemasan plastik), dan pola acak cahaya yang melewatinya telah diukur $^{[15]}$. Lensa L2 merupakan lensa pencitra utama. Tepat pada bidang fokus lensa, dipasang diafragma yang berfungsi sebagai tapis ruang dengan diameter lubang yang dapat diatur.

Pada bidang citra terbentuk citra $2,13 \mathrm{~cm} \times 3,1 \mathrm{~cm}$. Karena sensor penerima CCD berukuran $0,5 \mathrm{~cm} \times 0,6 \mathrm{~cm}$, tidak seluruh citra obyek dapat diterima. Untuk mengatasinya ditempatkan lensa pembantu L3 sejauh $8,2 \mathrm{~cm}$ (sama dengan jarak fokus L3) dari tapis ruang. Kamera CCD dipasang pada jarak $7 \mathrm{~cm}$ dari L3, sehingga citra pada sensor CCD berukuran $0,27 \mathrm{~cm} \times 0,40 \mathrm{~cm}$. 
Kamera CCD adalah ELMO TV Camera SE 362 yang mempunyai spesifikasi sebagai berikut:

1. Citra keluaran merupakan citra analog dengan skala keabuan

2. Ukuran daerah aktif CCD $0,5 \mathrm{~cm} \times 0,6 \mathrm{~cm}$

3. Tingkat pencahayaan minimum 0,08 lux.

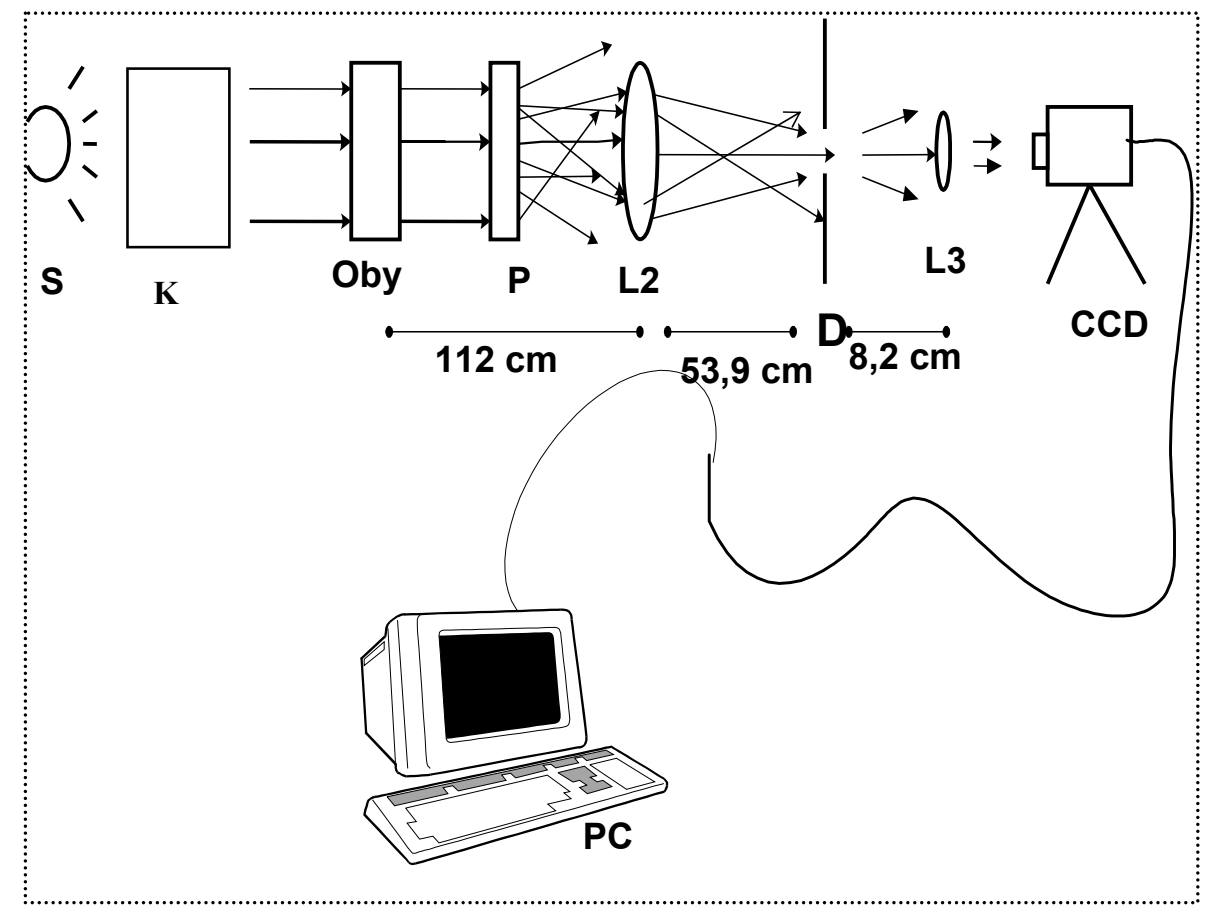

Gambar 3 Perangkat Perekam Citra.

Keterangan gambar:

$\mathrm{S}=$ sumber cahaya laser $\mathrm{He} \mathrm{Ne}$

$\mathrm{K}=$ kolimator untuk memperbesar berkas laser $\mathrm{He} \mathrm{Ne}$

Oby = obyek dua dimensi yang mempunyai dua faktor transmisi ( 0 dan 1$)$.

$\mathrm{P}=$ penghambur

L2 = lensa positif berjarak fokus $53,9 \mathrm{~cm}$ dengan diameter $5 \mathrm{~cm}$

$\mathrm{D}=$ tapis ruang

L3 = lensa positif berjarak fokus $8,2 \mathrm{~cm}$

$\mathrm{CCD}=$ kamera $\mathrm{CCD}$

$\mathrm{PC}=$ perangkat komputer dengan perangkat lunak Computer Eyes. 


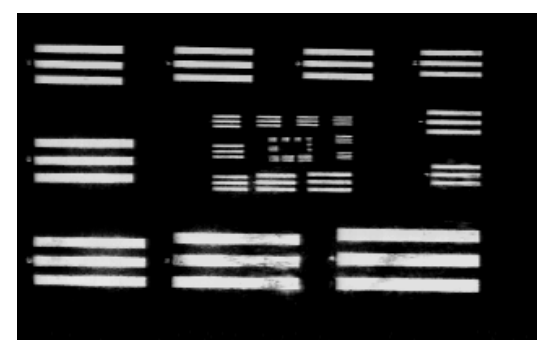

Gambar 4 Obyek yang digunakan.

\subsection{Perekaman}

Untuk menghasilkan efek kabut yang bergerak, setiap perekaman dilakukan dengan terlebih dulu menggeser kertas tissue dalam arah tegak lurus sumbu optik. Perekaman dilakukan pada 5 diameter tapis yang berbeda yaitu 0,75 $\mathrm{mm}, 1,0 \mathrm{~mm}, 1,6 \mathrm{~mm}, 2,1 \mathrm{~mm}$, dan $2,5 \mathrm{~mm}$, masing-masing sebanyak 30 kali perekaman. Salah satu hasil perekaman diperlihatkan pada Gambar 5.

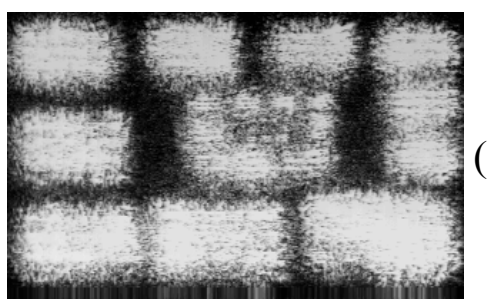

(a)
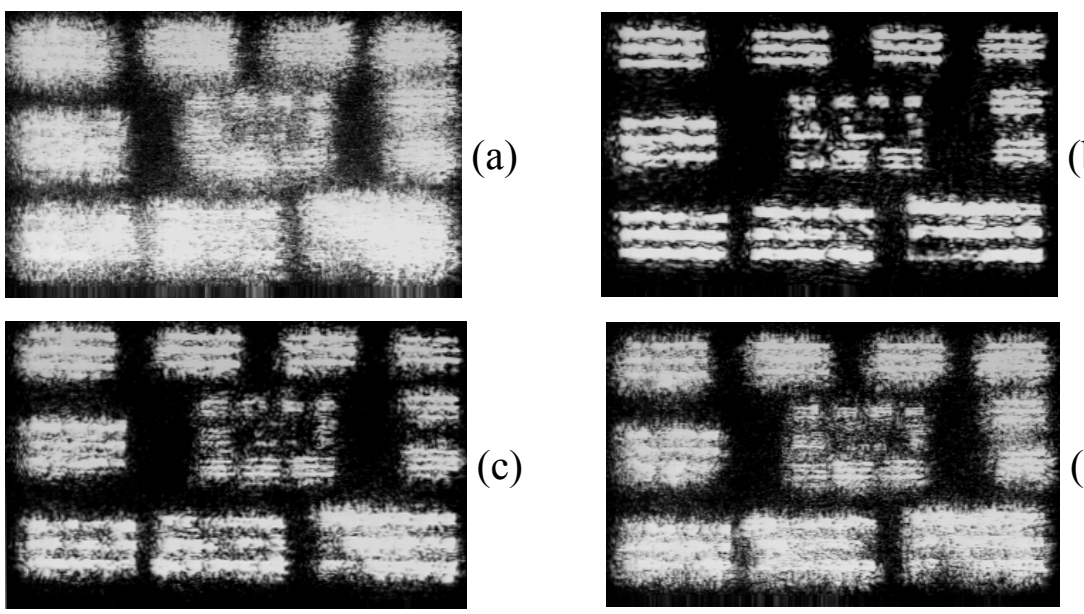

(c)

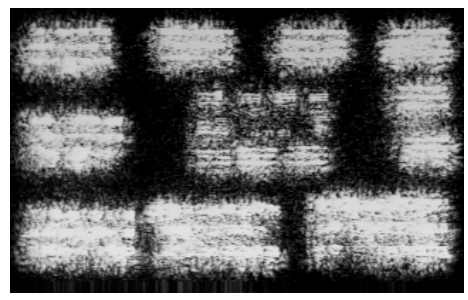

(d)
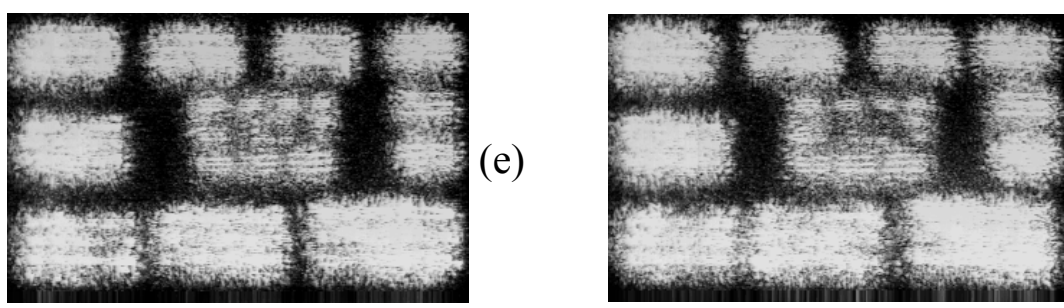

(f)

Gambar 5 Citra hasil dari perangkat optik: (a) tanpa tapis, dan dengan kertas tissue pada diameter tapis: (b) $0,75 \mathrm{~mm}$, (c) $1,0 \mathrm{~mm}$, (d) $1,6 \mathrm{~mm}$, (e) $2,1 \mathrm{~mm}$ dan (f) $2,5 \mathrm{~mm}$. 
Pada setiap bingkai (frame) pada Gambar 5 tampak noise yang ditimbulkan oleh spekel, yaitu dari interferensi acak antar bagian berkas laser. Karena intensitas spekel tergantung pada berkas laser yang menimbulkannya, noise seperti ini bersifat multiplikatif dan sangat menyerupai "salt noise", sehingga dapat diatasi dengan metode "or minimum" yang akan ditinjau. Sementara itu pada gabungan dari bingkai-bingkai, noise antar bingkai tidak berkorelasi dan ini menjadi dasar dari metode perata-rataan seperti pada pasal 3.1

Dari 30 citra hasil perekaman untuk setiap diameter tapis ruang, dilakukan perhitungan koefisien korelasi untuk setiap citra terhadap citra tanpa penghambur dan tapis ruang. Dilakukan juga perhitungan PSNR. Setelah itu dihitung rata-rata dari ke 30 harga koefisien korelasi dan PSNR, yang menghasilkan koefisien korelasi dan PSNR untuk sebuah bukaan tapis ruang, lihat Tabel 1.

Tabel 1 Harga rata-rata PSNR dan koefisien korelasi dari 30 citra yang diperoleh dari perangkat optik pada berbagai diameter tapis ruang.

\begin{tabular}{|c|c|c|}
\hline Diameter tapis (mm) & PSNR (dB) & Koefisien korelasi \\
\hline 0,75 & 9,21 & 0,364 \\
\hline 1,0 & 8,12 & 0,261 \\
\hline 1,6 & 7,76 & 0,368 \\
\hline 2,1 & 7,07 & 0,352 \\
\hline 2,5 & 6,17 & 0,332 \\
\hline
\end{tabular}

\subsection{Metoda Perata-rataan}

Perata-rataan dilakukan untuk 5, 10, 15, 20, 25 dan 30 citra, masing-masing pada diameter tapis seperti pada Gambar 5 dan Tabel 1. Pada setiap citra hasil pengolahan kemudian dihitung koefisien korelasi dan PSNR dengan citra tanpa penghambur dan tapis ruang sebagai acuan. Dari tiap bukaan tapis didapat citra dengan koefisien korelasi dan PSNR maksimum. Jumlah citra yang dirataratakan sehingga menghasilkan korelasi dan PSNR maksimum disebut jumlah optimum.

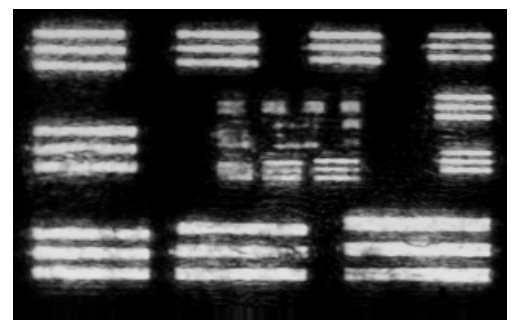

(a)

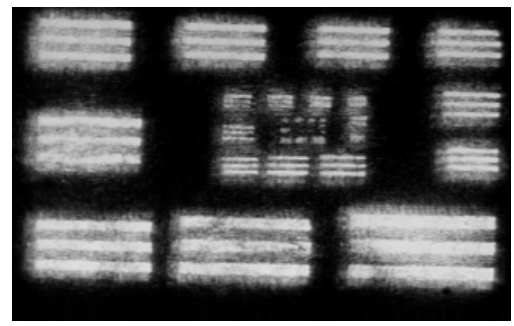

(b) 


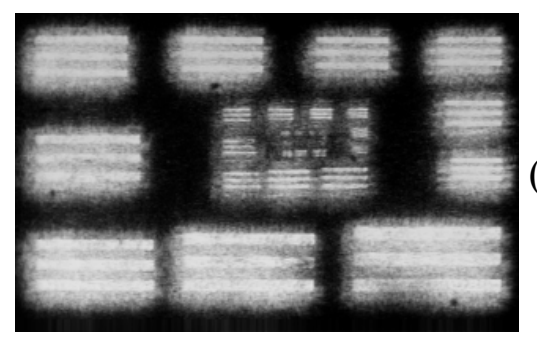

(c)

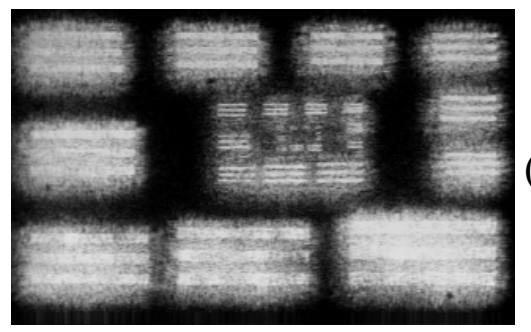

(d)

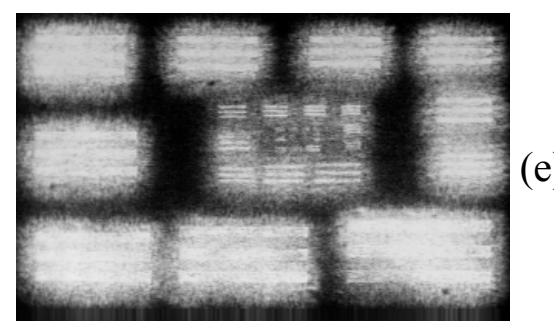

Gambar 6 Hasil perata-rataan optimum. (a) Diameter tapis 0,75 mm jumlah citra 10. (b) Diameter tapis $1 \mathrm{~mm}$ jumlah citraa 10. (c) Diameter tapis 1,6 mm jumlah citra 10. (d) Diameter tapis 2,1 mm jumlah citra 5. (e) Diameter tapis 2,5 mm jumlah citra 10 .

Didapatkan bahwa jumlah optimum citra yang dirata-ratakan ialah 10 , kecuali pada diameter tapis $2,1 \mathrm{~mm}$ jumlah optimum adalah 5 . Hasil pengolahannya diperlihatkan pada Gambar 6, sedangkan harga koefisien korelasi dan PSNR dicantumkan pada Tabel 2.

Tabel 2 Harga koefisien korelasi dan PSNR pada metoda perata-rataan dengan jumlah citra yang optimum.

\begin{tabular}{|c|c|c|c|}
\hline $\begin{array}{c}\text { Diameter tapis } \\
(\mathbf{m m})\end{array}$ & $\begin{array}{c}\text { Jumlah } \\
\text { citra }\end{array}$ & PSNR (dB) & $\begin{array}{c}\text { Koefisien } \\
\text { korelasi }\end{array}$ \\
\hline 0,75 & 10 & 9,84 & 0,401 \\
\hline 1,0 & 10 & 8,54 & 0,295 \\
\hline 1,6 & 10 & 8,06 & 0,404 \\
\hline 2,1 & 5 & 8,11 & 0,402 \\
\hline 2,5 & 10 & 6,6 & 0,381 \\
\hline
\end{tabular}

\subsection{Metoda "or minimum"}

Metoda "or minimum" diterapkan untuk diameter tapis dan jumlah citra yang sama seperti yang dilibatkan pada metoda perata-rataan.

Hasil "or minimum" yang optimum untuk masing-masing diameter tapis ruang dapat dilihat pada Gambar 7. Citra optimum tersebut didasarkan lebih pada 
pertimbangan koefisien korelasi yang terbesar, mengingat kenaikan PSNR pada metoda ini sudah lebih besar dari metoda perata-rataan ${ }^{[14]}$. Hasil perhitungan koefisien korelasi dan PSNR diberikan pada Tabel 3.

Tabel 3 Harga koefisien korelasi dan PSNR hasil metoda "or minimum" dengan jumlah citra yang optimum.

\begin{tabular}{|c|c|c|c|}
\hline $\begin{array}{c}\text { Diameter tapis } \\
(\mathbf{m m})\end{array}$ & $\begin{array}{c}\text { Jumlah } \\
\text { citra }\end{array}$ & PSNR (dB) & $\begin{array}{c}\text { Koefisien } \\
\text { korelasi }\end{array}$ \\
\hline 0,75 & 5 & 10,59 & 0,374 \\
\hline 1,0 & 20 & 11,50 & 0,321 \\
\hline 1,6 & 25 & 11,05 & 0,416 \\
\hline 2,1 & 25 & 11,07 & 0,416 \\
\hline 2,5 & 25 & 10,05 & 0,402 \\
\hline
\end{tabular}

\section{Analisa dan Pembahasan}

Dengan perangkat optik yang jauh dari rumit, telah diperoleh citra dari balik penghambur seperti yang diperlihatkan pada Gambar 5. Sesuai dengan efek tapis yang hanya meloloskan cahaya yang tidak terhambur, PSNR pada Tabel 1 semakin tinggi dengan mengecilnya diameter tapis.

Sementara itu koefisien korelasi cenderung naik kemudian turun lagi. Pada bukaan tapis yang kecil frekuensi ruang yang diloloskan lebih rendah dibandingkan pada diameter tapis yang lebih besar ${ }^{[12]}$. Akibatnya pada diameter tapis yang kecil, bagian berfrekuensi ruang tinggi tidak muncul dengan sempurna pada citra, sehingga koefisien korelasinya rendah. Semakin besar tapis, bagian citra tersebut semakin muncul sehingga koefisien korelasi meningkat. Tetapi jika diameter tapis lebih besar lagi, makin banyak noise yang turut diloloskan. Akibatnya korelasi latar belakang makin kecil yang pada akhirnya menurunkan koefisien korelasi citra keseluruhan. Pada Tabel 1 tampak bahwa harga koefisien korelasi maksimum didapatkan pada diameter tapis 1,6 $\mathrm{mm}$.
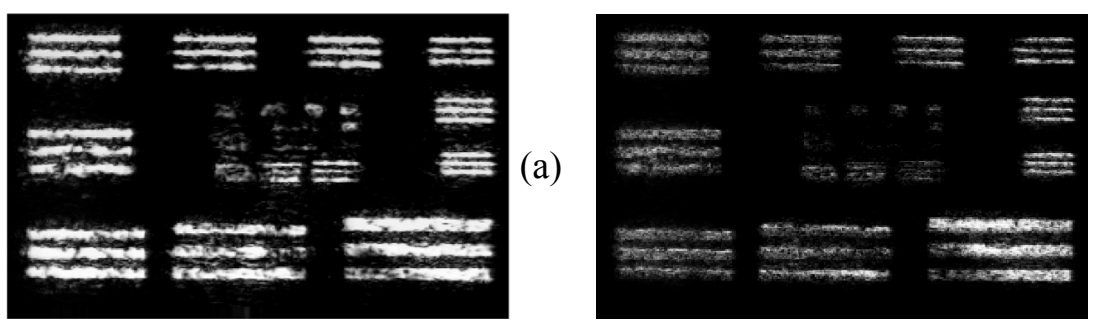

(b) 


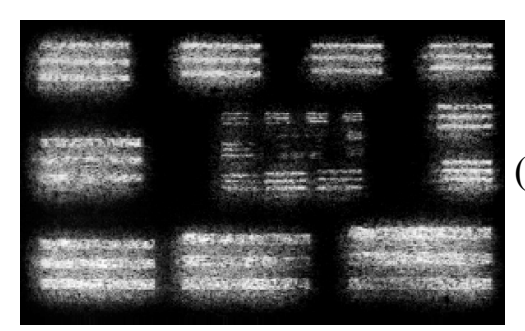

(c)

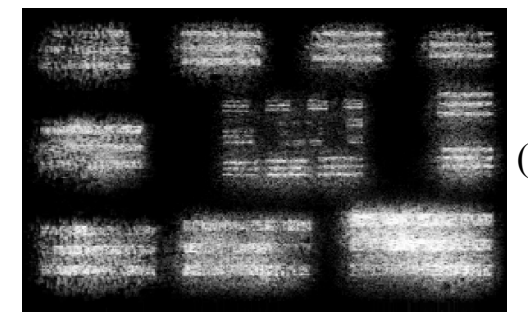

(d)

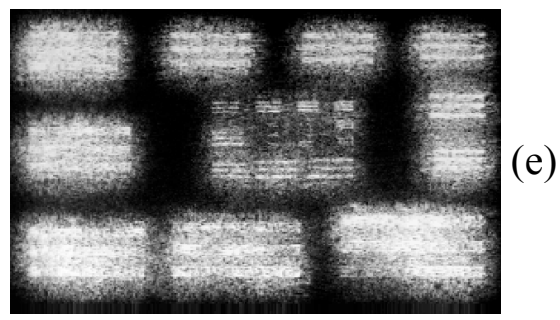

Gambar 7 Hasil “or minimum” yang optimum. (a) Diameter tapis $0,75 \mathrm{~mm}$ jumlah citra 5. (b) Diameter tapis $1 \mathrm{~mm}$ jumlah citra 20. (c) Diameter tapis 1,6 mm jumlah citra 25. (d) Diameter tapis $2,1 \mathrm{~mm}$ jumlah citra 25. (e) Diameter tapis $2,5 \mathrm{~mm}$ jumlah citra 15 .

Pada metoda perata-rataan (Tabel 2), perbaikan PSNR sangat sedikit dibandingkan Tabel 1. Yang paling besar adalah 1,04 dB pada diameter tapis ruang 2,1 $\mathrm{mm}$, yaitu hasil perata-rataan 5 citra. Dapat disimpulkan bahwa metoda perata-rataan tidak banyak mengurangi efek noise pada citra.

Perbaikan koefisien korelasipun sangat kecil, yang paling besar sekitar 0,05, yaitu hasil perata-rataan 30 citra pada harga diameter tapis $2,1 \mathrm{~mm}$. Sesungguhnya bila diamati secara visual terlihat bahwa hasil perata-rataan lebih memunculkan citra obyek tetapi dilatar belakangi oleh rata-rata dari noise. Ini sesuai dengan yang dikemukakan dalam Pasal 3.1.

Jumlah optimum citra yang dirata-ratakan berbeda-beda untuk setiap diameter tapis ruang. Berdasarkan perbaikan PSNR dan peningkatan koefisien korelasi jumlah optimum citra yang dirata-ratakan ialah 10, kecuali pada diameter tapis $2,1 \mathrm{~mm}$ jumlah optimum tersebut adalah 5 .

Dari harga PSNR dan koefisien korelasi pada metoda "or minimum" (Tabel 3) terlihat bahwa metoda ini cenderung mengurangi noise lebih baik dibandingkan metoda perata-rataan. Kenaikan terbanyak PSNR sebesar 4,0 pada diameter tapis ruang $2,1 \mathrm{~mm}$. Sementara kenaikan terbesar koefisien korelasi adalah 0,072 pada diameter tapis $2,5 \mathrm{~mm}$. 
Dapat disimpulkan bahwa metoda "or minimum" memperkecil noise, tetapi pada citra dengan noise yang rendah sebagian citra turut hilang, sehingga koefisien korelasi menjadi rendah. Jumlah citra optimum didasarkan pada pertimbangan koefisien korelasi yang terbesar, mengingat bahwa kenaikan PSNR pada metoda ini sudah lebih besar dari pada metoda perata-rataan.

\section{$6 \quad$ Kesimpulan}

Dengan menggunakan metoda optik yang sederhana dengan tapis ruang, telah diperoleh citra dari obyek di balik media penghambur. Kualitas citra kemudian diusahakan ditingkatkan dengan metoda digital yaitu dengan perata-rataan dan "or-minimum". Beberapa hasil kuantitatif diberikan berikut ini:

1. Pada hasil metode optik, PSNR turun dengan makin besarnya diameter tapis ruang. PSNR terbesar berharga $9,21 \mathrm{~dB}$ pada diameter tapis $0,75 \mathrm{~mm}$. Harga koefisien korelasi maksimum sebesar 0,368 didapatkan pada diameter tapis ruang $1,6 \mathrm{~mm}$.

2. Pada metoda perata-rataan, peningkatan PSNR terbesar terhadap hasil metoda optik adalah $0,54 \mathrm{~dB}$ dan perbaikan koefisien korelasi terbesar adalah 0,03 . Secara visual informasi citra terlihat lebih jelas hanya dilatar belakangi oleh noise yang cukup tinggi.

3. Terhadap hasil metoda optik, metoda "or minimum" mempunyai peningkatan PSNR terbesar 4,00 dB dan perbaikan koefisien korelasi terbesar adalah 0,07. Metoda ini mampu mengurangi noise lebih baik dibandingkan metoda perata-rataan.

\section{Daftar Pustaka}

1. Gayen, S. K., Alfano, R. R., Optical biomedical imaging, Mediscience Technology Corp, http://medisciencetech.com/opticalImg.htm.

2. Schultz, R. B., Jorge Ripoll, Visilis Ntziachristos, Noncontact optical tomography of turbid media, Optics Letters, 28 no. 18, 1701-1703 (2003).

3. Mils, K., Zee Zalevsky, Emmett N. Leith, Holographic generalized fisrtarriving light approach for resolving images viewed through a scattering medium, Applied Optics-IP, Vol. 41 no. 11, 2116-2121(2002).

4. Petoukhuvo, A. L., Wiendelt Steenbergen, Frits F.M. de Mul, Path length distribution and path-length-resolved Doppler measurement of multiply scattered photons by use of low-coheren interferometry, Optics Letters, 26 no.19, 1492-1494(2001).

5. Shih, M. P., Spectral holography for imaging through scattering media, Applied Optics-IP, Vol. 38 no. 5, 743-750(1999). 
6. Alfano, R. R., Ho, P. P., Wang, L., Ultrafast optical imaging of object in a scattering medium, Optical Imaging Patent Portfolio, no 5,371,368 (1994).

7. Alfano, R. R., Feng Liu, Wang, Q. Z., Ho, P., Wang, L. M., Liang, X., Ultrafast optical imaging of object in or behind scattering medium, Optical Imaging Patent Portfolio, no 5,710,429 (1998).

8. Yasui, T., Kaoru Minoshima, Hirokazu Matsumoto, Three-dimensional shape measurement of a diffusing surface by use of a femtosecond amplifiyng optical kerr gate, Applied Optics-OT, Vol. 39 No 1, 6571(2000).

9. Sesotyo, P. A., Analisa kecerahan batu urine pada citra x-ray dengan pembanding tulang menggunakan ekualisasi histogram, Tugas Akhir Teknik Fisika ITB (2002).

10. Blackwell, J. A., Using multiple images, http://www/regulusastro.com/regulus/papers/processing/, dikutip Maret 2004

11. Blackwell, J. A., CCD image processing, http://www/regulusastro.com/regulus/papers/processing/, dikutip Maret 2004.

12. Mustafa, E. J. \& Andrianto Handojo, Imaging through scattering media with lens and a spatial filter: system resolution and signal to noise ratio, Proceedings The $4^{\text {th }}$ Asian Control Conference, Singapore (2002).

13. Handojo A., Juliastuti, E. \& Wigajatri, R., Analisis gerakan kabut pada pencitraan melalui kabut dengan holografi, Proceedings PPI-KIM (1999).

14. Gonzalez, R. C., Woods, R. E., Digital Image Processing $\mathbf{2}^{\text {nd }}$ ed., Prentice Hall 2002.

15. Endang Juliastuti, Peningkatan kualitas citra dari obyek di balik penghambur dengan metoda optik dan digital, Disertasi ITB 2004.

16. Image Processing Toolbox User's Guide ver.2, The Math Works Inc., Massachusets, 1993

17. http://bmrc.barkeley.edu/courseware, dikutip Januari 2002. 